"Shakespeare and the Landscape of Death: Crossing the Boundaries of Life and the Afterlife." Shakespeare: Journal of the British Shakespeare Association, 8:2 (2012): 171-94.

This essay explores how denying or ignoring the meanings of the spaces scripted for the dead, or "deathscapes" as anthropologist Lily Kong calls them, can lead Shakespeare's characters to a spiritual death as well as a bodily one. I examine the cultural meanings of deathscapes in the early modern era--specifically the grave, graveyard and church--through the lens of the schism of Christianity caused by separation of Protestantism and Catholicism. When Hamlet, for example, makes the mistake of treating the spaces of the dead in ways that speak more to how Catholics define and use them, he puts himself in deadly peril. I argue, however, that this in no way makes Hamlet a "Catholic play," as some critics have in the past claimed. Instead, I show how Shakespeare reinforces the tenets and ideas of Protestantism by punishing Hamlet's lapses with such a thorough and unavoidable harshness that Hamlet's anti-Protestant actions and behaviours serve as a warning to audience members. The fact that Hamlet appears to treat the deathscape with more than a nod to the medieval notion of le danse macabre reinforces his weak and unstable nature, and leaves the audience in some doubt as to his chances of meeting with a favourable outcome in the afterlife.

Keywords: Hamlet, Macbeth, transgression, boundaries, graves, Catholicism, Protestantism, le danse macabre, memento mori, deathscape.

\title{
Shakespeare and the Landscape of Death: Crossing the Boundaries of Life and the
}

\section{Afterlife}

Sharon Emmerichs, Ph.D, Department of English, University of Missouri, USA 
Are not my days few? cease then, and let me alone, that I may take comfort a little, Before I go whence I shall not return, even to the land of darkness and the shadow of death. (King James Version, Job 10:20-1)

"Landscape," states Michael Reed in his book, The Landscape of Britain from the Beginnings to 1914, "is the autobiography of society. It reflects every aspect of . . social and economic preoccupations ... [and] .. . reflects, equally vividly, [the] moral and spiritual values" of a culture (230-1). Through the study of landscape, he argues, one can divine a broad spectrum of social, economic, moral and spiritual information about the society that shaped, moulded, and manipulated the land to adhere to various forms and functions representative of its cultural ideology. Similarly, Garrett A. Sullivan describes this phenomenon as "a way by which [landscape] ... simultaneously reflects and instantiates attitudes not only toward the land but to a whole range of social phenomena" (2). Few spaces and landscapes are as rigidly and culturally defined as the spaces used for and marked by the presence of the dead. Cemeteries, graveyards, battlefields, crypts, churches, cathedrals, ossuaries, mortuaries, charnel houses ... these spaces have attached to them a strict set of social, religious and governmental rules regarding human behaviour and custom that, if broken, result in transgressions of cultural taboos and codes of honour that redefine the transgressor as deviant or criminal. As anthropologist Nigel Barley put it in his book Grave Matters: A Lively History of Death Around the World, "[d]eath is such an important event that most cultures encapsulate it in myth and ritual, [and] give it at least a place in the world if not a justification" (63). In his seminal text, Issues of Death: Mortality and 
Identity in English Renaissance Tragedy, Michael Neill discusses this relationship as a "sense of the peculiar intimacy of culture and death [that] is as old as Genesis" (2). Such rituals - e.g., accepted ways to dispose of a body; mourning ceremonies for friends and family; societal rules regarding duration of mourning, appropriate dress, and ways of speaking about the dead, etc.not only help define a culture's attitudes towards death and dying, but serve to define its behaviours regarding these "places in the world," to shift Barley's metaphor of abstraction to a more concrete spatial signifier. And of course Shakespeare, always fascinated by the strengths and vagaries of human behaviour, puts his pen to the uneasy relationships that form between humankind and its ultimate resting places, or "deathscapes", as geographer Lily Kong calls them (1). Specifically, for the purposes of this article, I will examine Shakespeare's depictions of two particular deathscapes - the graveyard and the church — and explore how he uses these spaces both as a vehicle with which to emphasise a major flaw or deficiency of humanity inherent in his tragic characters and as a way to demonstrate the absolutely essential nature of culturally scripted boundaries regarding the landscapes of the dead.

Such landscapes can, using Catherine Belsey's analysis of historical objects and spaces, be considered readable texts through which we can glean information, meaning, signification, and understanding of a culture:

History at the level of the signifier treats signifying practices—maps, houses, clothing, tombs — as texts. Such 'documents' from the past are both substantial and legible. We can read them, as much as we can ever read anything, to the degree that we are familiar with the signifying practices of their moment. And since signifying practice in general, like language in particular, is in the first instance public, conventional, shared, learned, there is no reason why we 
should not learn to read the meanings of the past by immersing ourselves in the documents, even though we shall never understand them as native speakers. (Belsey 13)

Andrew Stables, in his essay "The Landscape and the 'Death of the Author"” published two years earlier, pushes for a definition of landscape that fits perfectly with both Belsey's analysis and my own purposes: "Certain landscape features have been given the status of texts since time immemorial, insofar as they have been regarded as human, cultural, and ideological constructs" (109). For the purposes of this essay, I shall be treating the landscape — both interior and exterior, natural and built — as a "document" or "text" that we can read in order to gain insight into Shakespeare's plays and characters. I will argue that when Shakespeare's tragic characters transgress boundaries of meaning in strictly defined deathscapes - that is, when they interact with the spaces of death in a manner considered culturally taboo- those characters suffer a similar violation that ends with an annihilation of morality (both of social or cultural ethics and laws, and the morality dictated by religious doctrine) and of the bodily and spiritual self. This article argues for an intimate link between the abuses of the physical landscape and various types of loss associated with those transgressions, including the loss of virtue, faith, safety, God's protection, and ultimately life itself. This failure is, for Shakespeare, universal and unrestricted to any specific demographic. Kings, princes, and peasants; men and women; foreigners and indigenous populations; clergy and laity_all must adhere to the cultural norms of landscape and space, both in the natural and the built environment, or suffer the consequences. The result is a glimpse into an early modern vision of community that recognises a desire to eliminate certain boundaries while demonstrating the absolute necessity for those boundaries' existence. Transgression, then, is as inevitable as Adam and Eve's Fall, for Shakespeare continually 
demonstrates that human curiosity, ambition, and desire will not be contained within such strict circumscription. Therefore, due to the fact that the Fall is scripted as "the lapse into selfconsciousness that renders humankind mortal" (Neill 2), transgression becomes as inevitable as death itself.

At the same time, I will use this article to examine the cultural meanings of deathscapes in the early modern era — specifically the grave, graveyard and church — through the lens of the schism of Christianity caused by separation of Protestantism and Catholicism. When Hamlet, Ophelia and Laertes, for example, make the mistake of treating the spaces of the dead in ways that speak more to how Catholics define and use them, they put themselves in deadly peril, both physically and morally. I argue, however, that this in no way makes Hamlet a "Catholic play," as some critics have in the past claimed. ${ }^{1}$ Instead, I show how Shakespeare reinforces the tenets and ideas of Protestantism by punishing his characters' lapses with such a thorough and unavoidable harshness that their anti-Protestant actions and behaviours serve as a warning to audience members - crossing those boundaries of meaning is extremely dangerous. Lisa Hopkins argues that Shakespeare is well aware of the problems fomented by the schism of these religious boundaries: "Shakespeare saw . . that the grievances of Catholics represented the most serious obstacle to religious unity and hence to political stability in Britain, and that they urgently needed to be addressed" (9). I argue that he does so through his portrayal of the ideological and doctrinal uses — and more particularly, misuses — of sacred landscapes. The fact that Hamlet appears to treat the deathscape with more than a nod to the medieval and popish notion of le danse macabre reinforces his weak and unstable nature, and leaves the audience in some doubt as to his chances of meeting with a favourable outcome in the afterlife. In this way, Shakespeare 
holds Hamlet up as an example of the importance of adhering to cultural norms, especially where the spaces of the dead are concerned.

\section{Interpretations of death and deathscapes}

Kong points out that the relationship between deathscapes and humanity is complicated and varied. "Deathscapes," she claims, "embody myriad meanings and values wrapped up in multiple narratives, inviting interpretation" (1). The very touch of the dead can irrevocably change the meaning of a landscape, but the perception of that meaning can be as diverse as the culture that defines it. According to the rules of Western culture, the burial of a body in a cemetery or graveyard can make the land sacred in the public imagination; the burial of a body in a playground or park can make the land profane. Archaeologists who dig up ancient bones and funerary artifacts are called scholars; those who dig up and plunder more recent burials are decried as grave robbers. Bodies buried in holy ground, as sanctified by a specific church or dogma, are deemed "blessed", while others buried in unconsecrated earth or an unmarked grave — or remain unburied entirely—may be construed as "damned".

However, it is not merely the presence of a deceased human body that influences how the landscape with which it interacts is defined; the landscape itself enacts meaning upon the corpse in a reciprocal relationship of symbiotic need. As Barley puts it, "The placing of the dead is never arbitrary. It is a clear act of classification and a statement of where they belong" (132), which clearly indicates that where a body is placed within a deathscape is just as important as how we interact with the corpse itself. This was as true for early modern England as it is for the postmodern present. In many cultures, including most religious sects, there exists a belief that strict adherence to mores regarding the disposal of a body - that is, attention to where the corpse 
is ultimately located as well as how it is laid out within that space—will allow the living to interpret what sort of person the deceased was in life, as well as have a direct impact on what happens to the soul or the spirit of the deceased in the afterlife. These practices are as varied as the cultures that enact them and span the course of human history, from how Homer describes Achilles' treatment of Hector's and Patroclus' corpses in the Iliad ${ }^{2}$ to the still-present orthodox Jewish belief that a body should, if at all possible, be buried within a day of death and must be buried whole, not cremated. ${ }^{3}$

The citizenry of the early modern era were no less concerned with proper practices, and were perhaps somewhat hyper-aware of the conventions of death and burial, having come out of the late Middle Ages ravaged by the worst of the Black Plague epidemics. The ability to once more carry out proper burial practices brought some stability and normality back to the frightening and painful business of dealing with death, for it was not so very long since "the Black Plague left corpses piled in the streets or in huge communal graves" (Spinrad 1) and "burial arrangements could break down during epidemics" (Houlbrook 333). Thomas Kyd illustrates the importance of these rituals in The Spanish Tragedy through the character of Andrea, a soldier slain in the course of war and denied access to heaven because "Charon, only boatman there, / Said that, my rites of burial not performed, / I might not sit amongst his passengers" (1.1.20-2). The implication that the only barrier to Andrea's entrance into heaven is the fact that his body remained unburied on the battlefield demonstrates the paramount importance of the deathscape itself, as the placement of the corpse is an integral part of those rites and rituals believed needed to enter the afterlife. Neill links this concept to the idea that the Renaissance continued to preserve the ancient pagan superstition that happiness beyond the grave was somehow contingent upon proper disposal and 
preservation of one's mortal remains - a belief that is probably reflected in the formulaic curse protecting Shakespeare's own tomb from disturbance. (265) Because Andrea transgressed the cultural mores of his particular deathscape, he was denied access to a spiritually fulfilling afterlife, and Shakespeare demonstrates this idea in Hamlet as well. As Hamlet observes Ophelia's funeral procession, he immediately recognises that "The corpse they follow did with desp'rate hand / Fordo it own life" $(5.1 .215-16),{ }^{4}$ thereby giving verisimilitude to the priest's complaint:

Her obsequies have been as far enlarged As we have warranties. Her death was doubtful, And but that great command o'ersways the order She should in ground unsanctified have lodged

Yet here she is allowed her virgin rites, Her maiden strewments, an the bringing home Of bell and burial.

No more be done.

We should profane the service of the dead To sing sage requiem and such rest to her As to peace-parted souls. (5.1.220-3, 226-8, 230-3) The priest obviously feels conflicted about allowing the consecrated earth to touch her corpse, worried that an unfit soul stained with the sin of self-murder will be inappropriately allowed into 
heaven. ${ }^{5}$ His discomfort conforms neatly to Neill's definition of the cemetery as an "oxymoron" that

serves as a reminder that a cemetery is itself ... a place of oblivion, and a site of memory; a place which annihilates all distinction ... and a site of monumental record; a place that both invites narrative and silences it. (234)

By burying Ophelia in the consecrated grave, the priest recognises the transgression of these oppositional meanings of space. His attitude is perfectly in keeping with the predominant Protestant early modern belief in which "[s]ocial categorisations of the living informed attitudes to the dead, perhaps particularly when the categorisation was itself involved with the cause of death, as with heretics and excommunicates, criminals ... and suicides" (Harding 174). Laertes' claim to the priest that "A minist'ring angel shall my sister be / When thou liest howling" (5.1.236) demonstrates his belief that the grave itself is Ophelia's primary avenue into Paradise, rather than the state of her soul upon her death. Likewise, Andrea's lack of a proper grave makes it impossible for him to enter heaven, again without reference to any virtues or grace he may have possessed in life. Deathscapes, then, are considered a necessary influence on the spiritual self as well as a way to dispose of the material self, according to cultural mores and doctrinal rules. The actual burial rites themselves serve to "complete the separation of the dead from the living as well as usher the soul of the dead" from this world into the next (Oakdale 107). Shakespeare, however, purposefully interrupts this "separation" of the living and the dead through the misuse of his deathscapes in order to emphasise the tragic, faulty nature of his protagonists as well as the immutable character of the deathscapes themselves. Hamlet and Ophelia both experience change through their interactions with the deathscapes, whereas the 
landscape itself does not; the meanings of those spaces, apparently, are not subject to interpretation. The boundaries of the deathscapes are absolute.

Deathscapes and their architecture, rituals, and material objects are intimately linked to ideas of memory, politics, sexual mores, religion, race, class, gender, and many other classifications by which a culture defines itself. As we have seen, deathscapes have specific and rigid definitions and boundaries, and when those boundaries are crossed we, as a culture, tend to experience unease and discomfort. For example, in churches and Christian graveyards, how and where a body is placed can reveal a great deal about who the deceased was in life. According to Barley,

bodies are buried with the head to the West and the feet to the East but the basic division has always been between North and South. The left-hand side of the altar (north) was called the gospel side for sinners, the right-hand (south) was the epistle side for the righteous... The unclean dead were buried to the north of the graveyard ... [and] a second hierarchy [inside the church] distinguished the rich who were near the altar from the poor who were near the door. (138)

Ralph Houlbrook claims that the "attractions of burial inside the church included social distinction, added protection for the corpse, and the supposed spiritual benefit of proximity to altars or the relics or images of saints" (329). Of course, these clear-cut definitions are for the comfort of the living, for the people who shudder to think of an eternity resting beside someone not of their class, status, or spiritual purity and therefore who enact safeguards against such a fate. Hamlet's priest expresses outrage at being forced by royal decree to bury Ophelia in consecrated ground, but because Ophelia “'Twas of some estate" (5.1.216), he must relent. 
Crossing the boundary between a "sinner's" versus a "righteous" burial obviously troubles the priest, but not as much Gertrude and Laertes are bothered by the thought that Ophelia's body would lie amidst those not of her class and rank with unconsecrated soil barring her entrance into heaven. Their transgression of such a sacred space not only contributes, I would argue, to their ultimate downfalls but actually foreshadows their destruction. Their willingness to break the cultural norms regarding the deathscapes becomes a part of the puzzle that audience can piece together to explain the reasons behind Gertrude's and Laertes' deaths. In this way, the deathscape becomes an active participant in how justice is enacted for the characters. This is not just an idea that exists in plays and stories, either, but is a very real part of medieval and early modern history and belief. When I visited Baddesley Clinton manor in Warwickshire in 2006, one of the National Trust personnel told me a story about a strange-looking mark on the wooden floor in the library. According to the tale, the owner of the house, a man named Nicholas Brome, had a Catholic priest ${ }^{6}$ living in his house and came home one day to find said priest "chucking his wife "neath the chin". It is said that right then and there Brome drew his knife and killed the priest, which left a large bloodstain on the floorboards. At his trial, it was decided that because of his rank and station in the community, no action would be taken against him in life - in fact, the royal pardon dated 7 May, 1496 still hangs on the wall in the main room of the manor. However, upon his death Brome was sentenced to be buried beneath the church porch so that the constant feet passing over his grave would keep him from enjoying his eternal rest. While some parts of the story may be apocryphal, ${ }^{7}$ modern archaeologists excavated the ground beneath the church porch and did, indeed, find the remains of a human skeleton there. As important a man as Nicholas Brome may have been in life, his deathscape was meant to have resonance and meaning for his very soul across an eternity. 
The lines between life and death — and the spaces both inhabit — are blurry at best in Shakespeare's plays, and he uses our subsequent anxiety about this conflation to explore a deviant villainy in his characters, most notably in his tragic protagonists. For example, the geographical distance between Macbeth's mortal commands of murder and the deaths of Banquo and Lady Macduff allows Macbeth to imagine an equal distance between himself and the identification of "murderer," and that space is significantly reduced when the ghost of Banquo narrows the gap by appearing in his house and takes Macbeth's place at his own table. The interior and exterior spaces of landscape restrict and define the behaviour of King Hamlet's ghost as it moves from one locality to another. Safe spaces become perilous, and those spaces reserved for life and the living are invaded and taken over by death and the deceased. ${ }^{8}$ Hopkins also examines this relationship and the inconstant boundaries between landscape and danger, though she couches her analysis in the geographical elements surrounding the play: "Margins, cliffedges, banks and borders are shifted to the centre in this world where something pivotal is out of joint, and it is indeed from the margins that we must be edified in our makings of meanings" (35). In this way, Shakespeare's deathscapes perform a vital role in determining the outcome of both plot and character, for those who respect the boundaries of his deathscapes survive while those who do not fall into destruction and despair.

\section{"The foul practice"}

It quickly becomes clear, therefore, that while Elizabethan theologians "agreed on the binary opposition of heaven and hell, soul and body, and God and Devil" (Calderwood 3), which indicates a strong investment for the early modern English man or woman to not only define but maintain the boundaries constructed between these disparate spaces, Shakespeare experiments 
with how these lines can be crossed, re-crossed, and broken down. By doing so, he ultimately emphasises the importance of those boundaries, since those who cross such lines tend to come to very bad ends. One message we can take away from characters such as Hamlet and Macbeth is that trafficking with the dead is good for dramatic tension and story, but extremely dangerous to the immortal soul. In part, this idea is a direct result of the shift from Catholicism to Protestantism that took place in the early sixteenth century, which brought with it a new perspective through which to envision death and the link between the body and soul. By Shakespeare's time, Protestant reformers had moved away from what A.N. Galpern calls "a cult of the living in service of the dead" (149), which encapsulates the Catholic view of the relationship between life and death, or, as Stephen Greenblatt describes it, "[n]ot only doctrine . . . but also chants, gestures, images, and the very air that the faithful breathed said the same thing: the border between this world and the afterlife was not firmly and irrevocably closed" (Purgatory 18). Nancy Caciola goes on to elaborate upon these boundaries between not only the still-living and the dead, but the dead and their own life experiences:

To place the dead permanently ... was a complex process. Once the spirit left the body it was displaced from its accustomed habitation, and the location of its continued existence was a topic of some dispute. Theologians held that the spirits of the dead were placed immediately according to their merits, entering into one realm of a tripartite afterlife, but this was not a consensus viewpoint. The bourgeois inhabitants of some towns . . believed that certain shades of the dead might remain displaced for some time, particularly the ghosts of those who had died a 'bad death' that was sudden or violent. Such spirits might wander the earth as maleficent spirits seeking bodies. In short, the dead might 
mourn their own death, their desolate existence in exile from the sensory experiences of embodiment. (66-7)

By the time Shakespeare's play was written, such inherently Catholic visions of the boundaries between the dead and the living were considered highly heretical—at least by law, if not within actual day-to-day practice. Many critics over the years have commented on the seemingly contradictory images and invocations of Catholicism and Protestantism in Hamlet; Paul D. Stegner writes that "Shakespeare's concentration on private confessional signals a type of doctrinal simultaneity in which vestiges of the traditional religion coexist, trouble, and even threaten to undermine the current belief system" (106). Alison A. Chapman claims that "the presence of a ghost seemingly straight out of purgatory has always put the play's theological cards on the table, as it were, but scholars . . . have further explored the ways in which the play echoes and queries a range of contemporary theological debates" (111). Hopkins tells us that "[t]he boundaries between the worlds of the living and dead in this play are also fluid, unstable, and easily permeated, but to troubling rather than titillating or energizing effect" (45). In short, viewing Hamlet though the lens of what Beatrice Groves calls "the psychic rupture of the Reformation" (400) is not uncommon; however, the overwhelming majority of critics tend to focus on the character of Hamlet himself, whereas I am more interested-for the purposes of this discussion - to examine how Hamlet's blurry doctrinal boundaries are represented specifically in his relationships with death and deathscapes.

The audience's first indication that boundaries have been transgressed occurs when the ghost of Hamlet's father transgresses the boundaries of life and the afterlife to walk the earth once more. The understanding that the consecration of his body into his grave was insufficient to lay his spirit to rest becomes the first transgression of the cultural meanings of the deathscape 
and sets the scene for Hamlet to follow his father's problematic example, as old King Hamlet obviously expected him of him in thought and action. The fact that Hamlet does not question his father's transgressions of the grave, and subsequently commits his own, as we will see, becomes a foreshadowing of his own tragic downfall and destruction. The Reformation attempted to entirely change the way people thought about death and the boundaries between this life and the afterlife, and this is certainly represented in the literature of the age, particularly in the tragic dramas. Neill goes so far as to claim that "the extraordinary burgeoning of tragic drama in late Elizabethan and Jacobean England ... was among the principal instruments by which the culture of early modern England reinvented death" (3). The new doctrine of the Reformation focused on the Protestant insistence that "there could be no commerce and exchange between the quick and the dead, that the living could do nothing to alter the condition of the deceased, and that the dead had no knowledge of the affairs of the living" (Gordon and Marshall 10). Philip Schwyzer describes the Reformation as "radically transform[ing] the spiritual status of human remains. No longer could fragmented body parts serve as the conduits through which spiritual aid flowed between the dead and the living. The bones, one might say, had gone dead" (110). Those boundaries became effectively closed, and any transgression across those lines constituted a breach of religious doctrine and resulted in criminal and heretical behaviour. Even the "burial practices, as rites of passage in moments of social realignment, were strongly affected by the move towards reform" (Döring 27-8). Therefore, from this perspective we can interpret Hamlet's weakness, abuse of power, corruption, madness, and ultimately his death as stemming from not only putting that first foot over the line that separates "the quick and the dead" but from his attempt to bring back the more Catholic ideas and attitudes regarding ways to envision relationships with those who have passed on and the deathscapes they inhabit. His great flaw, 
then-that element that lies at the heart of all of his other problems that Robert B. Bennett defines as Hamlet's tendency to be "too sensitive, too shy, too contemplative, too melancholy, too death-bent, too sexually confused, too credulous, too egocentric" (77) — can be traced back to this one transgression, the crossing of this single boundary.

His eagerness and willingness to deal with his father's ghost demonstrates this flaw from the very beginning of the play and immediately sets him apart from the other characters who look upon the ghost with much more suspicion and distrust. Those standing upon the rampart who first see the ghost recognise it immediately as a thing of danger; the ghost is presented to the characters - and to the audience - in "complete armour, holding a truncheon, with his beaver up" (1.1), which indicates that the ghost is prepared for war, and thusly for the dangers that accompany it. Horatio comments that the vision "harrows me with fear and wonder" (1.1.42) and Marcellus describes it as "this dreaded sight" (24). Barnardo exclaims to Horatio, "You tremble and look pale" (51) upon seeing it and Marcellus later asks, "Shall I strike at it with my partisan?" (121) as if it were a dangerous enemy. The men's reactions are universally fearful, defensive and violent. Hamlet, on the other hand, upon hearing the news that his father's ghost haunts the castle grounds, merely says, "'Tis very strange" (1.2.220), and when confronted with the actual ghost seems to consider alternative meanings of its appearance:

Angels and ministers of grace defend us!

Be thou a spirit of health or goblin damned,

Bring with thee airs from heaven or blasts from hell,

Be thy intents wicked or charitable,

Thou com'st in such a questionable shape

That I will speak to thee. (1.4.20-5) 
He, unlike Barnardo, Marcellus and Horatio, contemplates a potentially positive interpretation of the ghost's visit. He allows that the ghost's intentions can be "healthy", "heavenly" and “charitable". Hamlet's transgression begins with his inability or unwillingness to interpret the ghost's appearance as an abomination, and continues with his sustained, albeit unsuccessful, attempts to satisfy the desires of the dead. He is willing — even eager - to break that boundary between "the quick and the dead", which indicates a dangerous movement away from accepted and enforced Protestant doctrine.

As such, Hamlet is very much a living man "in service of the dead" when he promises the ghost of his father to

... wipe away all trivial fond records,

All saws of books, all forms, all pressures past, That youth and observation copied there, And thy commandment all alone shall live Within the book and volume of my brain Unmixed with baser matter. (1.5.99-104)

In making such a vow, he fails to "contemplate the deceased as exemplifications of virtue and achievement, rather than as persons with whom any kind of relationship could be maintained" (Gordon and Marshall 10) and instead participates in a very Catholic attempt to release his father from a definitively Purgatorial suffering. At the heart of Catholic belief in the late Middle Ages was the "overwhelming preoccupation of clergy and laity alike ... with the safe transition of . . souls from this world to the next, above all with the shortening and easing of their stay in Purgatory" (Duffy 301). The Ghost's description of his fate, that he is

Doomed for a certain term to walk the night, 
And for the day confined to fast in fires

Till the foul crimes done in my days of nature

Are burnt and purged away ... (1.5.10-3),

seems to invoke images of what David Beauregard calls "Purgatory and the sacraments of penance and extreme unction" (46). Even Shakespeare's use of the word "purged" in this passage echoes the meaning and intention behind the concept of "purgatory", for it is that space in which the taints and sins from human life are slowly stripped away before entering the kingdom of Heaven. Beauregard goes on to note several other seemingly Catholic movements within Hamlet, including the fact that Hamlet swears "by Saint Patrick" (1.5.140), the saint best known for supposedly discovering the entrance to Purgatory in the middle of Ireland:

... the son of God, appearing to him, led him to a deserted place where he showed him a round cave, dark within, and said to him, 'Whoever in true repentance and constancy of faith enters this cave for one day and night will be purified there from all the sins they have committed against God during all their lives' (Gardiner 136).

However, while Beauregard claims that "Shakespeare's play can better be understood from a Catholic perspective" (45) and that "Hamlet does not appear to be a very Protestant play" (46), I would instead argue quite the opposite, that the death and destruction that comes as a result of Hamlet's anti-Protestant pursuits in his interactions with death and the ghost of his father, as well as in how he interacts with the play's deathscapes—which I will examine in a moment—in fact reinforces the clerical early modern desire to eschew Catholic practices from religious and devotional life. Hamlet's fate acts as a warning, an admonition to playgoers not to emulate his stubborn adherence to Catholic ideals and practices. Just as Hamlet is undone by Laertes' poison, 
Laertes' claim that "The foul practice / Hath turned itself on me. Lo, here I lie, / Never to rise again" (5.2.270-72) mirrors the state of Hamlet's soul upon his death, wherein the "foul practice" of Catholicism has doomed his soul "never to rise" to the kingdom of heaven.

It is this subtle, yet striking handling of doctrinal juxtapositions that separates Shakespeare from his contemporaries, despite the fact that they often shared or fuelled his fascination with ghosts and the supernatural. Other writers and playwrights of the Renaissance tended to adhere more strictly to the Protestant ideas of "binary oppositions" in their works, choosing not to so obviously dabble with either the fascinations with or dangers of forbidden rituals. Shakespeare's adaptation of Kyd's The Spanish Tragedy demonstrates this quite clearly, for the ghosts of Andrea and King Hamlet are hardly equivalent in this way. Kyd maintains the boundary between life and death much more faithfully than Shakespeare does, as we realise when the ghost of Andrea cannot pass through the "veil" from the afterlife to the living world on his own:

Forthwith, Revenge, [Prosperpine] rounded thee in th' ear,

And bade thee lead me through the gates of Horn,

Where dreams have passage in the silent night.

No sooner had she spoke but we were here,

(I wot not how) in twinkling of an eye. (1.1.81-5)

In this same vein, John Webster in The Duchess of Malfi also acknowledges and reinforces the impassable boundary between life and death, for the Duchess, during a conversation with her waiting woman Cariola, cries, 'O $\mathrm{O}$, that it were possible we might / But hold some two days' conference with the dead!” (4.2.27-8). Christopher Marlowe achieves the same effect when Faustus ponders which profession he should choose. "Be a physician Faustus," (1.1.14) he 
advises himself, and yet he rejects the idea because it would not allow him to bring people back from the dead:

Yet art thou still but Faustus, and a man wouldst thou make man to live eternally?

Or being dead, raise them to life again?

Then this profession were to be esteemed.

Physic farewell! (1.1.23-7)

This implication that the ability to manipulate the boundary between life and death is a perverted form of power serves to emphasise that the boundary is, in itself, the natural state of the world and necessary to keep the "binary opposites" of life and death separated. Yet Shakespeare, amongst all his contemporaries, appears to most often blur that line, to treat it as illusory; as Tobias Döring puts it, "Shakespeare's tragedy is so disquieting because it . . . defamiliarizes mourning rites and gestures" (103). For instance, upon hearing of his wife's death, Macbeth calls life "but a walking shadow" (5.5.23), intimating not only that all human beings are fated to die, but that life and death themselves are not as separate and distinct as the early modern Englishman and -woman might prefer to imagine. His use of the word "shadow", so often a euphemism for or allusion to the words "death" and "ghost", to describe "life" allows for a much closer relationship between the two. Likewise, Antigonus in The Winter's Tale muses upon the transparent nature of the gateway between life and death:

I have heard, but not believed, The spirits o' the dead May walk again: if such thing be, thy mother 
Appear'd to me last night, for ne'er was dream

So like a waking. (3.3.15-9)

Along the same lines, the ghost of King Hamlet, unlike Kyd's portrayal of the impotent Andrea, seems to appear and disappear at will—at least during the night hours. However, despite the fact that the way by which he can traverse the boundaries between the worlds of the living and dead are shrouded in mystery, for he claims he is unable to "tell the secrets of my prison-house" to his son (1.5.18), he appears to have much more freedom and autonomy than Andrea. After all, King Hamlet can interact with the living and allows himself to be seen by a multitude of people, whereas Andrea is positioned merely as an observer, unable to influence his surroundings or speak to the other characters. He only speaks to the allegorical character of Revenge, who is very clear in setting the boundaries for Andrea's participation in the events to follow: "Here sit we down to see the mystery, / And serve for Chorus in this Tragedy" (1.1.90-1). Kyd, it would seem, is more invested in maintaining that separation between the living and the dead than is Shakespeare. In fact, Isabella voices this need as she laments the death of her son Horatio:

So that you say, this herb will purge the eye, And this the head?

Ah, but none of them will purge the heart. No, there's no medicine left for my disease, Nor any physic to recure the dead. (3.8.1-5) Hamlet, on the other hand, constantly attempts to forge an immutable connection between the living and the dead that goes even beyond his relationship with his father's ghost. In the graveyard scene in Act 5, he explains to Horatio how Alexander the Great's body might still have a practical application to the living world: 
Alexander died, Alexander was buried, Alexander returneth into dust, the dust is earth, of earth we make loam, and why of that loam whereto he was converted might they not stop a beer-barrel? (5.1.204-7)

By intimating that the dead still have purpose and function within living society, Hamlet brushes aside the accepted boundaries between life and death like the very dust he speaks of, and it is not surprising that Horatio considers this hypothetical—and perhaps heretical—academic question "too curious ... to consider so" (5.1.201), especially considering that Hamlet's musings are remarkably close to those put forth by the Catholic Luis de Granada in his book Of Prayer and

\section{Meditation:}

a time maie happen, when some buildinge maie be made neare unto thy grave, (be it never so gaie, and sumptuous,) and that they maie digge for some earthe out of the same to make morter for a walle, and so shall thy seelie bodie (beinge now changed into earth) become afterwardes an earthen walle, although it be at this present the most noble bodie and most delicately cherished of all bodies in the worlde. And how manie bodies of Kinges and Emperors trowest thou have come already to this promotion. (qtd. in Prosser 225)

It is generally accepted that Shakespeare was familiar with de Granada's text, though critics have disparate views regarding its importance to his plays. Though Stephen Greenblatt claims that "Shakespeare had evidently read and absorbed the Catholic book", he makes no comment nor ascribes any import to it, merely stating that Shakespeare "shared some of the same cultural points of reference" with known Catholic sympathisers (Will 158). It seems to me, however, that Shakespeare firmly plants the character of Hamlet in both camps in order to demonstrate the 
dangers of straddling that particular fence. Hamlet's movement from Protestant to Catholic rhetoric mirrors his change from victim to murderer, his shift from play-actor to true madman, and, ultimately, his metamorphosis from a vital, living man to a corpse. As such, transgressing the accepted boundaries of deathscapes has weakened his own boundary between his life and his death; for Shakespeare, there appears to be an intimate link between the cultural definitions of the landscape and of the self. By emphasizing this connection, he draws attention to Hamlet's very humanity, and the fragility of the elements that construct such humanity. A human, Shakespeare implies, is subject to the same rules of meaning, the same cultural constructs as are the spaces of the dead - and they are just as easily broken when those meanings are transgressed.

\section{"Ask for me tomorrow and you shall find me a grave man."}

Just as Horatio is befuddled by Hamlet's attempts to give form and function to the dead within the realm of the living, some early modern notions and attitudes towards death and deathscapes might surprise a postmodern reader, who desires to "notice to the least possible degree that death has occurred" (Ariès 90). To us, it may appear odd and somewhat sacrilegious or disrespectful that while digging Ophelia's grave, the Clowns unearth and toss up the skulls of previous occupants of that piece of earth. "There's another" (5.1.95) Hamlet says casually as one Clown pitches a second skull from the grave, and the modern reader or audience member is left wondering about the inherent contradictions of this attitude. If a proper burial in the proper place is necessary for the spirit to reach heaven, does it not follow that in order to remain in the blissful afterlife the corpse must remain in its allotted deathscape? According to early modern thinking, not at all. As historian Philippe Ariès put it, during the medieval and early modern periods, 
As yet unborn was the modern idea that the dead person should be installed in a sort of house unto himself, a house of which he was the perpetual owner or at least the long-term tenant, a house in which he would be at home and from which he could not be evicted. In the Middle Ages and even as late as the sixteenth and seventeenth centuries the exact destination of one's bones was of little concern so long as they remained near the saints, or in the church, near the altar of the Virgin or of the Holy Sacrament. Thus the body was entrusted to the Church. It made little difference what the Church saw fit to do with these bodies so long as they remained within its holy precincts. (22)

Even the bodies of the wealthy buried under the flagstones of the church floor were fair game to be dug up and used to adorn the charnel houses within the churches and crypts (see Figures 1 and 2). According to Clayton G. MacKenzie, during the early modern period, funerary practices frequently involved disinterment. A corpse, having been buried for a period in the ground of a cemetery or ... under the flagstones in an adjoining church, was often disinterred. The bones, cleaned of whatever mortal debris still clung to them, were polished and piled in charnel houses, churchyards in which the bones of the dead were neatly stacked and stored.

Thomas Dekker makes reference to this practice in his 1607 play, The Whore of Babylon when a one of the cardinals laments that:

Vast Charnel-houses, where our fathers heads

Slept on the cold hard pillowes of the earth, Are emptied now, and chang'd to drinking roomes, 
Or vaults for baser office. ${ }^{9}$

Shakespeare himself exhibited a certain trepidation regarding this practice, as we can see by the epitaph he wrote for his own gravestone:

Good friend, for Jesus' sake forbear

To dig the dust enclosed here.

Blessed be the man that spares these stones,

And cursed be he that moves my bones.

Therefore, Hamlet's sangfroid regarding the Clowns' actions and handling of bones becomes somewhat clearer in light of this knowledge. Susan Zimmerman further breaks down the early modern attitudes regarding the dead body in terms of the Protestant Reformation and rejection of Catholic rituals. "Late medieval Catholicism," she claims, "focused intensely on the implications of the Incarnation, on the profoundly ambiguous and deeply sacred connections between the corporeal and spiritual" whereas Protestant reformers viewed this bond as a "dangerously distorted relationship between body and soul" (8). This anxiety, she explains, "prompted an effort to reformulate materiality as definitively dead" (8, her emphasis), wherein materiality can be expressed as the corpse itself. The connection between the physical and the spiritual has been demystified and boundaries erected to keep them separate and distinct. A homily from Certayne sermons or homelies appoynted by the Kynges Maiestie to be declared and redde ${ }^{10}$ entitled "Against Peril of Idolatry and Superfluous decking of Churches", first published in English in 1547 , demonstrates well this desire for doctrinal separation. The homily is an argument against the display of idols and images in churches and claims that "they bee dead, haue eyes and see not, hands and feele not, feete and cannot goe, \&c, and therefore they cannot be fit similitudes of the liuing GOD" (17). The implication that the dead human body, that is, what is cast off once 
the soul departs for whatever realm it shall eternally inhabit, is as base and earthly as "dead stocks, stones, and metals" (17) serves to demystify—or what Zimmerman refers to as "killing"- the corpse (9) in terms of spiritual and religious dogma, ${ }^{11}$ and in this context the Clowns' actions in digging up already-inhabited graves, as well as Hamlet's treatment of poor Yorick's bones, makes sense. Neill defines the Clowns as "antic figures of the danse macabre" representing "a death that is at once personal and common" (85), which emphasises Hamlet's transgression of the definitive cultural-i.e., Protestant - meaning of the gravesite as he once again echoes the words of Luis de Granada. Hamlet's rhetorical questions, "Where be your gibes now, your gambols, your songs, your flashes of merriment that were wont to set the table on a roar?" (5.1.184-87) are remarkably similar to de Granada's query of "Is this that pleasunt rowlinge tongue, that talked so eloquently, and made such goodlie discourses?" (qtd. in Beauregard 47). At nearly every turn in his interaction with the dead and their deathscapes, Hamlet is tarred with the brush of heresy, which ultimately foreshadows his own imminent experiences with death and the grave.

These interactions with the bones of the dead in Hamlet, as well as with Ophelia's somewhat fresher corpse within her actual grave, are reminiscent of the aforementioned cultural phenomenon that had begun in the Middle Ages called le danse macabre, or the Dance of Death, which depicted —often quite graphically—the dead and living coexisting and interacting with each other in a visual demonstration of Greenblatt's claim that in the medieval understanding "the border between this world and the afterlife was not firmly and irrevocably closed" (Purgatory 18). As Arnold Stein puts it, le danse macabre is a "dance in which living figures represented surprise and reluctance while their partners, decaying corpses, showed an extreme liveliness" (11). The skeletal figures and representations of putrescent and eviscerated bodies of 
the dead not only serve as a grotesque reminder of what is to come, but also allow the dead to still play an active role within the community of the living. Susan Zimmerman describes this death-dance between the living and the dead as

a dance that laments and a lamentation that dances; it is a 'revel of monstrous uncreation' ... that states a grotesque simulacrum of both the living and the dead, or rather an eerie community of the living dead ... If death is what the human subject both desires and abhors, then the warring tonalities of the Dance of Death allow the spectator an ironic intimation of this ambivalence, one that is, importantly, communal, a kind of mirror imaging in which the spectator is both inside and outside the Dance. (196)

This claim of community was extraordinarily important to the English medieval population. It is hardly surprising that a people as familiar with the prevalence and physicality of death would rate it so high amongst its list of concerns; as William J. Bouwsma put it, "death was very close to the forefront of general consciousness" (125) in the English Middle Ages, and this concept was partly responsible for why it was so difficult for Protestant reformers to shift the practices and beliefs of the early modern way of thinking about death from one of community with the dead to one of autonomy from the dead. Plague was still prevalent in England during Shakespeare's time - in fact, all of London's theatres closed down in response to plague outbreaks in 1593, 1603, and 1608. The inhabitants of England often did, literally, move amongst the dead, and the constant fear of joining their ranks necessitated building coping strategies that allowed for detachment while acknowledging a communal experience and anxiety. The Dance of Death was one such coping strategy, and Hamlet's intimacy with Yorick's bones 
provides us with a stark visual example of that juxtaposition of the living and the dead in which Hamlet is, in Zimmerman's words, "both inside and outside the Dance".

Within this Dance, Shakespeare seems particularly invested in his interactions with material elements of death and deathscapes, specifically with memento mori. Henry E. Jacobs writes that,

The memento mori of a revenger may be quite literal: Hieronimo keeps Horatio's rotting corpse, Hoffman preserves his father's skeleton, and Vendice clutches Gloriana's death's head. These tableaux of the living and the dead are derived, at least in part, from well-established medieval traditions. In most cases, they represent a displacement of orthodox religious ideology and a superscription of the perverted and subversive religion of revenge over normative religious discourse. Shakespeare's use of the emblem and the tradition, however, is remarkable in its fidelity to medieval tradition and the orthodox discourse of the memento mori. (96)

Yorick's bones become a memento mori, allowing Hamlet a glimpse into his own future-a future defined by death, though he does not at first recognise it. This memento mori, Latin for "Remember you shall die," fails, however, for Hamlet does not, at this time, have his own death clearly in his mind. Perhaps this is not surprising when we think about Robert N. Watson's claim that "[f]or all the pious and rational warnings that death is universal, human beings are notoriously ready to disbelieve in their own mortality. This was apparently as characteristic of the [early modern population] as it is of us" (29). However, in a play about a death in which the protagonist is supposed to bring about the death of a murderer, and in which he consistently muses upon his own death and even goes so far as to contemplate suicide and more than once 
displays a longing for self-annihilation, Hamlet's words and actions in this scene are remarkably devoid of any acknowledgement of his own death. He addresses Yorick's skull and charges it to “get thee to my lady's chamber" (5.1.188) as a memento mori for her — an injunction to remember her own ultimate and unavoidable fate — but he fails to take the warning himself and eventually tosses the skull aside without another thought. Watson points out one other instance of Hamlet's general cluelessness regarding his interactions with the dead as portents of his own fate:

[The ghost's] insistent 'Remember me' translates into 'memento mori,' not an extension of life, but an invitation into death. Why, then, is Hamlet so jolly by the end of a visitation that hints at purgatorial torments, reveals earthy horrors, and assigns him a brutal and predictably fatal task? (84)

Throughout the play, it seems, Hamlet cannot recognise the signs leading to his own death, and his problems stem from the fact that his participation in le danse macabre hearkens back to a pre-Reformation ideal of a reciprocal relationship between "the quick and the dead". Nowhere in the play is this seen as clearly as within the grave itself.

Laertes, overcome with grief at his sister's death, cries, "Hold off the earth a while, / Till I have caught her once more in mine arms", at which point he leaps into her grave. "Now pile your dust upon the quick and dead" he instructs, "Till of this flat a mountain you have made / To o'ertop old Pelion, or the skyish head / Of blue Olympus" (5.1.245-50). Hamlet, outraged by this action, declares himself to the gathered funeral participants:

What is he whose grief

Bears such an emphasis, whose phrase of sorrow

Conjures the wand'ring stars and makes them stand 
Like wonder-wounded hearers? This is I,

Hamlet the Dane. (5.1.250-4),

after which he leaps into the grave with Laertes. ${ }^{12}$ In this striking visual image, the audience now has a vision of three different stages of death - the newly dead (Ophelia), the long-dead (Yorick), and the living dead (Hamlet and Laertes). Even if the early modern playgoer had never seen Hamlet before, he or she would undoubtedly know quite well the traditions of the tragic genre. Hamlet's fate was sealed as soon as he agreed to the "predictably fatal task", as Watson called it, that the ghost of his father set for him. Likewise, Laertes' movement in entering his sister's grave results in a strong foreshadowing of his own fate. Just as Mercutio acknowledges his unavoidable and imminent fate by stating that "Ask for me tomorrow, and you shall find me a grave man" (3.1.97-8), despite the fact that he is still, for the time being, amongst the living, Laertes and Hamlet are shown as much more literal "grave men", having actually taken up residence in a known and familiar deathscape. As the inhabitant of Protestant England knew quite well, one does not enter the grave and come back from it again.

This juxtaposition of life and death, or rather three different stages of death, upon the very deathscape they inhabit represents yet another form of memento mori familiar to the early modern audience. Funerary artifacts such as tombs and monuments represented ways in which the early modern vision of death still carried elements of the medieval notions of le danse macabre. In her discussion of how the Dance of Death is represented in English funerary accoutrements, Claire Gittings claims that the late Middle Ages is when, The dance of death emerges as a popular theme and when worm-infested corpses, or transi, appear in tomb sculpture. A particularly striking example is the brass to Ralph Hamsterely, engraved about 1510, at Oddington, 
Oxfordshire; the shrouded skeleton is being eaten by enormous worms which weave between the bones and slither through the eyesockets and jaws. A threedimensional representation, dating from 1477, occurs at Ewelme in the same county, where the dignified alabaster figure of Alice, Duchess of Suffolk, reposing on a table tomb, constrasts starkly with the repulsive cadaver glimpsed through the arches beneath. (34-5)

This pairing of a lifelike image of the deceased with a grotesque representation of a corpse already caught in the throes of decomposition was not terribly unusual, especially for the well-todo. In Figures 3 to 5, it is clear that, just as in Hamlet's graveyard scene, there is more than one type of death represented. The resemblances are unmistakable; both figures are similarly posed and both are emblematic of the person who has died, yet their visual effects are completely different. Zimmerman explains that this concurrence of images is,

[t]he irremediable mortality of human life [which] points to the tenuousness of the body's conceptual construction and establishes the dead body as the entity that must somehow be accommodated by the collapsed categories of its predecessor. . .. [T] he fearsomeness of the corpse resides in its putrefaction, or unbecoming; that is, in the dissolution of those boundaries that mark the body's former union of parts. (2, her emphases)

The topmost figure on the tomb is clearly meant to portray such a "union of parts", or the ideal body as the deceased would like to be remembered. Gittings attributes these images to "the growing desire of testators to leave a durable record of their physical appearance through monuments" in the late Middle Ages (34). The hands are raised in prayer and the cheeks are still flushed with healthy, sanguine colour. The brightly painted clothes and rich gold accouterments 
also perpetuate the notion that this figure is merely enjoying a particularly pious sleep as it remains lying in state for all time. The figure below (Figure 4), separated from his twin by a solid slab of stone, has clearly shed his mortal coil. He is skeletal, naked, and his arms lay limp and motionless by his sides. He is subsumed beneath the "ideal" effigy, his grave becoming a display for the horrified onlooker, and yet we are still being asked to define this figure in terms of "its predecessor". In looking at Figure 5, we can see that this tomb from the 16th century has done away with the death-effigy altogether, replacing the humanistic figure with a scattering of disarticulated and anonymous bones, which would make recognition of self even more distant, yet at the same time offers the spectator a glimpse into his or her own inevitable future. These figures, both whole-skeletal and scattered, are the memento mori, and even though perhaps our "gorge rises at it", it still serves as a warning that "to this favour [we] must come" $(5.1 .183,189$ 90).

The deathscape of the grave defines Hamlet and Laertes just as these deathscape monuments define the dead they represent. All the elements are present - the idealised dead body in the form of the still-beautiful and as-yet uncorrupted flesh of Ophelia; the corrupted or disarticulated body in the form of Yorick, which serves as the memento mori and reminder of mortality; and finally, the spectators, or the ones who most need to heed that warning. However, when they jump into Ophelia's open grave, Hamlet and Laertes suddenly change from spectator to a part of the monument itself, which is perhaps the most startling boundary Shakespeare crosses in the entire play. Not only are they claiming a space specifically reserved for the dead, but Ophelia now acts as their second self, the corpse that is literally beneath their bodies, just as shown in the funerary monuments. Their actions in essence change her status from the "ideal body" to the "corrupt body", which also serves to reinforce the priest's initial interpretation of 
her death and his repugnance at her self-slain corpse. Laertes, acting from uncontrolled grief, is not so much seeking self-destruction in his demand to be buried with his sister as he is attempting to circumvent the Protestant separation of the living and the dead. His invocation of Pelion and Olympus, the two mountains of Greek mythology, brings to mind a time when it was believed the gods were intimately involved in mortals' lives and it was considered possible to bring a loved one back from the underworld. In this moment he yearns to be an Orpheus, or for Ophelia to be a Persephone, able to transcend those boundaries that their Christian faith keeps firmly and irrevocably locked. Hamlet, on the other hand, enters the grave only as an angered response to Laertes' initial action, not from any grief of his own. "I loved Ophelia" he claims. "Forty thousand brothers / Could not, with all their quantity of love, / Make up my sum" (5.1. 266-8). Hamlet challenges Laertes to a battle in which he claims to match and outdo any show of love Laertes might demonstrate:

'Swounds, show me what thou'lt do.

Woot weep, woot fight, woot fast, woot tear thyself,

Woot drink up eisel, eat a crocodile?

I'll do't. Dost thou come here to whine,

To outface me with leaping in her grave?

Be buried quick with her, and so will I.

And if thou prate of mountains, let them throw

Millions of acres on us, till our ground,

Singeing his pate against the burning zone,

Make Ossa like a wart. Nay, an thou'lt mouth,

I'll rant as well as thou. (5.1.270-81) 
Hamlet does not focus on his grief for Ophelia, but on his anger towards Laertes in this speech. Laertes leapt into the grave first, thereby "outfacing" Hamlet and claiming the dead and the deathscape as his own, and Hamlet must fight to recover what he feels he has lost—not Ophelia herself but the memento mori that would forever bind her to him. Hamlet himself contributes to the debasement Ophelia's corpse by turning her funeral into a testosterone-driven territorial battle, which aids in her sublimation from ideal to corrupt dead. In doing so, the burial rites become a contest and the grave a battlefield, which serves as yet another foreshadowing of Hamlet's own death-if the playgoer needed yet another clue.

At the end of Hamlet's life, Horatio shows for his friend the same quietly desperate, yet somehow inevitably futile hope for happiness in the afterlife that Laertes bestowed upon his sister: "Good night, sweet prince, / And flights of angels sing thee to thy rest" (5.2.312-3), he mourns. However, just as the priest's speech leaves the audience in little doubt as to Ophelia's ultimate destiny, Horatio's next words are a stronger indication of the more likely outcome of Hamlet's fate: "Why does the drum come hither?" (5.2.314). The threateningly martial instrument of conquest, struck with great violence and effort to create the sound, ultimately becomes the memento mori of Hamlet's legacy, and of his doom. His transgressions upon—and of- the earth have sealed his fate. 


\section{Works Cited}

Ariès, Philippe, Western Attitudes Towards Death: From the Middle Ages to the Present. Baltimore: The Johns Hopkins UP, 1974. Print.

Barley, Nigel. Grave Matters: A Lively History of Death Around the World. New York: Henry Holt and Company, 1995. Print.

Beauregard, David. “'Great Commands O'Ersways the Order': Purgatory, Revenge, and Maimed Rites in Hamlet." Religion and the Arts. 2(2007): 45-73. Print.

Belsey, Catherine. Shakespeare and the Loss of Eden: The Construction of Family Values in Early Modern Culture. New Brunswick: Rutgers UP, 1999. Print.

Bennett, Robert B. "Hamlet and the Burden of Knowledge." Shakespeare Studies. 15(1982): 7797. Print.

Bouwsma, William J. The Waning of the Renaissance: 1550-1640. New Haven: Yale UP, 2000. Print.

Caciola, Nancy. "Spirit seeking bodies: death, possession and communal memory in the Middle Ages." The Place of the Dead: Death and Remembrance in Late Medieval and Early Modern Europe. Bruce Gordon and Peter Marshall, Eds. Cambridge: Cambridge UP, 2000. Print.

Calderwood, James L. Shakespeare and the Denial of Death. Amherst: U. of Mass. P, 1987. Print.

Certaine Sermons or Homilies Appointed to be Read in Churches In the Time of Queen Elizabeth I: 1547-1571 (1623 Edition). Mary Ellen Rickey and Thomas B. Stroup, Eds. Gainesville, FL: Scholars Facsimiles \& Reprints, 1968. Print.

Chapman, Alison A. "Ophelia's 'Old Lauds': Madness and Hagiography in Hamlet." Medieval \& Renaissance Drama in England. 20(2000): 111-35. Print.

Döring, Tobias. Performances of Mourning in Shakespearean Theatre and Early Modern Culture. New York: MacMillan, 2006. Print.

Duffy, Eamon. The Stripping of the Altars: Traditional Religion in England c. 1400-1580. New Haven: Yale UP, 1992. Print.

Galpern, A.N. "The Legacy of Late Medieval Religion in Sixteenth-Century Champagne." The Pursuit of Holiness in Late Medieval and Renaissance Religion. C. Trinkaus and H.O. Oberman Eds. E.J. Brill, Leiden, 1974. Print.

Gardiner, Eileen, ed. Visions of Heaven and Hell Before Dante. NY: Italica Press, 1989. Print.

Gittings, Claire. Death, Burial and the Individual in Early Modern England. London: Croom Helm, 1984. Print. 
Gordon, Bruce and Peter Marshall. The Place of the Dead: Death and Remembrance in Late Medieval and Early Modern Europe. Bruce Gordon and Peter Marshall, Eds. Cambridge: Cambridge UP, 2000. Print.

Greenblatt, Stephen. Will in the World: How Shakespeare Became Shakespeare. New York: W.W. Norton \& Co., 2004. Print.

---, Hamlet in Purgatory. Princeton: Princeton UP, 2001. Print.

Groves, Beatrice. review of Curran, John E., Jr. "Hamlet, Protestantism, and the mourning of contingency: not to be." Review of English Studies 58:235(2007): 400-402. Print.

Harding, Vanessa. "Whose body? A study of attitudes towards the dead body in early modern Paris." The Place of the Dead: Death and Remembrance in Late Medieval and Early Modern Europe. Bruce Gordon and Peter Marshall, Eds. Cambridge: Cambridge UP 2000. Print.

Homer. The Iliad. Trans. Richard Lattimore. U of Chicago P, 1951. Print.

Hopkins, Lisa. Shakespeare on the Edge: Border-Crossing in the Tragedies and the Henriad. Burlington, VT: Ashgate Publishing, 2005. Print.

Houlbrook, Ralph. Death, Religion, and the Family in England, 1480-1750. Oxford: Clarendon Press, 1998. Print.

Jacobs, Henry E. "Shakespeare, revenge tragedy, and the ideology of Memento Mori." Shakespeare Survey. 21(1993): 96-108. Print.

Kong, Lily. "Cemeteries and Columbaria, Memorials and Mausoleums: Narrative and Interpretation in the Study of Deathscapes in Geography." Australian Geographical Studies. 37.1 (March, 1999): 1-10. Print.

Kyd, Thomas. "The Spanish Tragedy." Four Revenge Tragedies. Katharine Eisaman Maus, Ed. Oxford: Oxford UP, 2008. Print.

MacKenzie, Clayton G. Emblems of Mortality: Iconographic Experiments in Shakespeare's Theatre. Lanham: University Press of America, 2000. Print.

Marlowe, Christopher. Dr. Faustus The Norton Anthology of English Literature. Abrams et.al. Eds. New York: W.W. Norton \& Co, 1993. Print.

Neill, Michael. Issues of Death: Mortality and Identity in English Renaissance Tragedy. Oxford: Clarendon Press, 1997. Print.

Oakdale, Suzanne. "Forgetting the Dead, Remembering Enemies." Interacting with the Dead: Perspectives on Mortuary Archaeology for the New Millennium. Gainesville: UP of Florida, 2005. Print. 
Prosser, Eleanor. Hamlet and Revenge, Second Edition. Stanford: Stanford UP, 1971. Print.

Reed, Michael. The Landscape of Britain: from the Beginnings to 1914. Savage, MD: Barnes and Noble Printing, 1990. Print.

Spinrad, Phoebe. The Summons of Death on the Medieval and Renaissance English Stage. Columbus: Ohio State UP, 1987. Print.

Stables, Andrew. "The Landscape and the 'Death of the Author"'. Canadian Journal of Environmental Education. 2.1 (1997): 104-13. Print.

Stegner, Paul D. "“Try What Repentance Can': Hamlet, Confession, and the Extraction of Interiority.” Shakespeare Studies. 35(2007): 105-29. Print.

Stein, Arnold. The House of Death: Messages from the English Renaissance. Baltimore: The Johns Hopkins UP, 1986. Print.

Sullivan, Garrett. The Drama of Landscape: Land, Property, and Social Relations on the Early Modern Stage. Stanford: Stanford UP, 1998. Print.

The Bible: Authorized King James Version with Apocrypha. Oxford: Oxford UP, 2008. Print.

Watson, Robert N. The Rest is Silence: Death as Annihilation in the English Renaissance. Berkeley: U of California P., 1994. Print.

Webster, John. The Duchess of Malfi. The Norton Anthology of English Literature. Abrams et.al. Eds. New York: W.W. Norton \& Co, 1993. Print.

William Shakespeare: The Complete Works. Stanley Wells and Gary Taylor, eds. Oxford: Clarendon Press, 2005. Print.

Zimmerman, Susan. The Early Modern Corpse and Shakespeare's Theatre. Edinburgh UP, 2005. Print. 
${ }^{1}$ See, for example, Catholic Theology in Shakespeare's Plays by David N. Beauregard (2008), and Through Shakespeare's Eyes: Seeing the Catholic Presence in the Plays by Joseph Pearce (2010).

2 Achilles and his Myrmidons mutilated Hector's body so that he would be an outcast in the afterlife, and he specifically refused to "give Hektor, Priam's son, to the fire" but rather gave the body to "the dogs, to feast on" (Lattimore 455) in order to deny his spirit safe passage.

${ }^{3}$ Deuteronomy 21:23

${ }^{4}$ All quotes from Shakespeare plays, unless otherwise noted, are taken from William Shakespeare: The Complete Works Oxford: Clarendon Press, 2005, edited by Stanley Wells and Gary Taylor.

${ }^{5}$ In Shakespeare's time, suicide had long been deemed both a civil and ecclesiastical crime. In fact, St. Augustine was the first Christian to publicly denounce suicide as a sin in his text City of God in the early $5^{\text {th }}$ century and the $6^{\text {th }}$ century saw the beginnings of using burial practices as punishment for those who succeed in committing self-murder. It wasn't until the $13^{\text {th }}$ century, however, with the fiery rhetoric of St. Thomas Aquinas, that the notion of suicide as the worst possible sin-i.e., the sin from which one cannot repent—really took off.

${ }^{6}$ Baddesley Clinton is best known for its "priest-holes", in which the residents of the house harbored Catholics during the religiously tumultuous Tudor dynasty.

${ }^{7}$ Scientists have tested the "bloodstained" floorboards and have found that the age of the wood does not match the time period of the story. The boards are too young and had been placed in the library after Brome's death. Some have speculated that the boards were moved from a different part of the house, others that later owners replaced the boards to remove the grisly reminder of their family's crime.

${ }^{8}$ I am certain it is no accident that the ghost of King Hamlet appears to Hamlet in Gertrude's bedchamber - very likely the place that Hamlet was conceived — or that Lady Macbeth's death took place in a similar location.

${ }^{9}$ From the University of Virginia's online library. Dekker, Thomas. The Whore of Babylon. 1607. < http://xtf.lib.virginia.edu/xtf/view?docId=chadwyck_evd/uvaGenText/tei/chevd_V1.0056.xml;ch unk.id=d8;toc.depth $=100 ;$ brand $=$ default $>$

${ }^{10}$ These homilies were republished in 1623 , and the text I am actually quoting is Certaine Sermons or Homilies 1547-1571 (1623 Edition), edited by Mary Ellen Rickey and Thomas B. Stroup.

${ }^{11}$ Zimmerman does explain, however that it took some time for this idea to take root in the "communal imagination" (9).

${ }^{12}$ This stage direction appears in the Q1 version of the play, but not in the more reliable Q2 version. However, most modern editors and critics include the action based on its inclusion in Q1. 